DOI: https://doi.org/10.32839/2304-5809/2021-3-91-70

уДК 341.018

Шурупова О.О., Панфілова Ю.М. Київський міжнародний університет

\title{
ОБСТАВИНИ, ЩО ВИКЛЮЧАЮТЬ ВІДПОВІДАЛЬНІСТЬ ДЕРЖАВ
}

Анотація. Досліджено теоретичні питання кваліфікації поведінки держав щодо наявних обставин, які звільняють їі від відповідальності. У відповідності з основним принципом права міжнародної відповідальності кожне міжнародно-правне діяння тягне за собою міжнародно-правову відповідальність. Тим не менше, в міжнародному праві склався певний перелік обставин, при існуванні яких відповідальність не наступає. Зокрема, в Статтях про відповідальність держав за міжнародно-протиправні діяння, розроблених Комісією міжнародного права ООН та прийнятих в якості додатку до Резолюції Генеральної Асамблеї ООН 56/83 від 12 грудня 2001 р., визначаються обставини, що виключають протиправність діяння. Глава V Статей закріплюе вичерпний перелік таких обставин, за наявності котрих суб'єкт не несе відповідальності за діяння, яке не відповідае тому, що вимагає від нього міжнародне зобов’язання. Ці обставини застосовуються до будь-яких міжнародних зобов'язань, будь то договірна чи звичаєва норма, тобто незалежно від їх джерела: «обставина, що виключає протиправність, застосовується відносно не тільки договірних, але й недоговірних зобов'язань». Однією із найважливіших умов, що гарантуе правильну юридичну кваліфікацію певних фрактичних ситуації, коли держава може посилатися на обставини, які звільняють її від міжнародно-правової відповідальності, $є$ розвиненість диспозицій міжнародно-правових норм, що встановлюють юридично-фрактичні підстави, при наявності яких виключається відповідальність держави за міжнародні правопорушення. У статті здійснюеться теоретичне дослідження правової природи та функціональної ролі обставин, які звільняють державу від міжнародно-правової відповідальності на основі узагальнення міжнародної практики і міжнародно-правової доктрини в світлі основоположних норм і принципів сучасного міжнародного права. Особливу увагу приділено таким обставинам, як згода держави, контрзаходи, форс-мажор, стан необхідності та самооборона.

Ключові слова: міжнародна відповідальність держав, міжнародно-правове діяння, міжнародне правопорушення, правова природа, юридична кваліфікація, Комісії міжнародного права ООН.

Shurupova Oleksandra, Pafilova Yuliya Kyiv International University

\section{CIRCUMSTANCES THAT EXCLUDE THE RESPONSIBILITY OF STATES}

Summary. Theoretical issues of qualification of the behavior of states in relation to the existing circumstances that release it from responsibility are studied. In accordance with the basic principle of the law of international responsibility, every international legal act entails international legal responsibility. Nevertheless, there is a list of circumstances in international law in which liability does not arise. In particular, the Articles on the Liability of States for Internationally Wrongful Acts, developed by the UN Commission on International Law and adopted as an appendix to UN General Assembly Resolution 56/83 of 12 December 2001, set out the circumstances that preclude the unlawfulness of an act. Chapter V of the Articles establishes an exhaustive list of such circumstances, in the presence of which the subject is not liable for an act that does not correspond to what is required of him by an international obligation. These circumstances apply to any international obligation, whether contractual or customary, that is, regardless of their source: "a circumstance that precludes illegality applies not only to contractual but also to non-contractual obligations". One of the most important conditions that guarantees the correct legal qualification of certain factual situations, when the state can refer to the circumstances that release it from international legal responsibility, is the development of dispositions of international law, establishing legal and factual grounds in which liability is excluded, states for international offenses. The article provides a theoretical study of the legal nature and functional role of circumstances that release the state from international legal responsibility on the basis of generalization of international practice and international legal doctrine in the light of fundamental norms and principles of modern international law. Particular attention is paid to such circumstances as state consent, countermeasures, force majeure, necessity and self-defense. The article deals with the theoretical study of the legal nature and functional role of circumstances that relieve the state of international legal responsibility on the basis of the generalization of international practice and international legal doctrine in the light of the fundamental norms and principles of contemporary international law. Particular attention is paid to such circumstances as the consent of the state, countermeasures, force majeure, state of necessity and self-defense.

Keywords: international responsibility of states, international legal action, international offense, legal nature, legal qualification, UN Commission on International Law.

Постановка проблеми. Загальна та об'ективна защікавленість держав у стабільності міжнародного правопорядку, додержання міжнародної законності та чітке фрункціонування механізму міжнародно-правового регулювання надає особливого значення вдосконаленню нормативної основи системи обставин, які звільняють державу від міжнародно- правової відповідальності з урахуванням вимог загальновизнаних норм і принципів сучасного міжнародного права. В діючих міжнародно-правових актах правова природа і сутнісна орієнтація обставин, які звільняють державу від міжнародно-правової відповідальності, визначаються фррагментарно, а в ряді випадків, розпливчасто, що, безумовно, знижує едрективність діючих між- 
народно-правових норм, що встановлюють зазначені обставини.

Актуальність проблематики міжнародно-правової відповідальності безпосередньо пов'язана 3 триваючою роботою Комісї міжнародного права ООН, з підготовки. Проекту статей про відповідальність держав за міжнародно-протиправні діяння - проекту майбутньої міжнародної конвенції про відповідальність держав. Серед проблем, що викликають в цій сфрері, великий науково-практичний інтерес, далеко не останне місце займає проблема обставин, що виключають відповідальність держави в міжнародному праві. Слід зазначити, що в науці і практиці міжнародного права немае едності з багатьох важливих питань, що стосуються обставин виключення відповідальності держави. Однак не викликає сумнівів, що зважаючи на специфіку міжнародного права різне тлумачення та розуміння норм, що встановлюють ці обставини, може справити негативний вплив на фрункціонування всієї системи міжнародно-правових норм. Так, у разі надмірного розширення кола обставин, що виключають міжнародну відповідальність держави, може створитися певна можливість для уникнення відповідальності, а при звуженні цього кола виникають передумови для покладання відповідальності на державу, поведінка якого фрактично не складає міжнародного правопорушення.

Аналіз останніх досліджень і публікацій. При написанні наукової статті були використані міжнародно-правові акти універсального і регіонального характеру, рішення міжнародних судових і арбітражних органів, документальні джерела і матеріали Організащії Об'єднаних Нащій, в тому числі досліджень Комісії міжнародного права ООН з питання про кодифрікацію і прогресивний розвиток міжнародно-правових норм, що регулюють відповідальність держав за міжнародні правопорушення та обставини що виключають відповідальність держав.

Різні аспекти даної теми досліджувалися в працях таких українських та зарубіжних науковців, як: Бекяшев К. О., Дмитріев А. I., Лукашук I. I., Анцелевич Г. О., Буроменський М. В., Мацко А. С., Левін Д. Б., Баймуратов М. О., Тункін Г. І., Тускоз Ж. та інші.

Мета статті. Дослідити характер та коло обставин, що виключають відповідальність держави в міжнародному праві.

Виклад основного матеріалу. Відповідно до загальних принципів міжнародної відповідальності держав будь-яке міжнародно-правове діяння держави спричиняе міжнародну відповідальність цієї держави. Міжнародно-правове діяння буде завжди в наявності, якщо держава своїм поводженням порушуе своє міжнародне зобов'язання. Тому правильно слід оцінити позицію, що склалася в доктрині міжнародного права, відповідно до якої з цих основних принципів не може бути будь-яких винятків доти, поки міжнародне зобов'язання дійсне для даної держави.

Проте в повсякденній дійсності можуть мати місце обставини, що перешкоджають на даному етапі виконанню державою своїх зобов'язань, у тому числі з виконання їх у строк, або обумовлюють їх не виконуваність. Ці обставини можуть виключити міжнародно-правову відповідаль- ність держави, через те, що тут відсутне протиправне діяння держави.

Звільнення від відповідальності - це зняття із суб'єкта міжнародного права обов'язку ліквідації наслідків здійсненого ним діяння, яке спричинило відповідальність.

Обставини, що виключають відповідальність держав (спричиняють звільнення від відповідальності) - це факти, дії та явища, доведеність існування яких на момент здійснення правопорушення знімає із суб'єкта міжнародного права обов'язок відшкодування збитків, якщо правопорушення було спричинене цими фрактами, діями чи явищами.

При цьому, якщо склад правопорушення не повний чи відсутній взагалі, відповідно і не настає міжнародна відповідальність. Відповідальність може виключатися як за наявності вини суб'єкта, так і за її відсутності (абсолютна відповідальність) [11 с. 143].

Обставини, що виключають протиправність діяння, повинні бути юридично значимими i, відповідно, визначатися нормами міжнародного права. У цьому відношенні КМП ООН при розробці Проекту статей про відповідальність держав розробила в 1980 році статті 29-34 про обставини, що виключають відповідальність держав. До таких обставин належать:

- згода держави;

- контрзаходи;

- фрорс-мажор і непередбачений випадок;

- лихо;

- стан необхідності;

- самооборона.

У відношенні обставини, що носить найменування «згода держави», стаття 29 Проекту говорить: «Правомірним способом дана згода держави на вчинення іншою державою певного діяння, що не відповідає зобов'язанню останньої у відношенні першої держави, виключає протиправність цього діяння, оскільки це діяння знаходиться в межах вищевказаної згоди».

Наприклад, введення іноземних військ на територію держави звичайно розцінюеться як серйозне порушення суверенітету держави, а найчастіше, як акт агресії. Проте така дія не буде визнана такою, якщо вона здійснена на прохання або за згодою держави.

Отже, така згода фрактично $е$ міжнародною угодою, що виникає між управочиненим i зобов'язаним суб'єктами міжнародного права. Вона стосується не зміни або скасування даного міжнародного зобов'язання, а лише незастосування його у встановленому конкретному випадку.

Виключення відповідальності держави уразі згоди наступає за наявності таких умов:

- згода держави повинна бути міжнародноправомірною;

- згода повинна бути ясно вираженою, а не такою, що припускається;

- згода повинна передувати вчиненню дії;

- діяння, на вчинення якого отримана згода, повинно відбуватися в межах узгоджених його умов, що стосуються місця, часу, засобів і інших обставин діяльності зобов'язаної держави [4, с. 333].

Проте міжнародне право пред'являе певні вимоги і до держави, що дає згоду: держава вправі давати згоду на діяльність іншої держави тільки 
в межах своєї території, а також стосовно своїх суверенних прав і юрисдикції, що діють в межах недержавної території (континентальний шельф, виключна економічна зона, відкрите море і т.д.); згода управомоченої держави не може бути дана на вчинення дій, що суперечать імперативним нормам міжнародного права (наприклад, згода на використання своєї території для вчинення агресії у відношенні третьої держави). Під відповідними заходами стосовно міжнародно-протиправного діяння, що виключають відповідальність держави, стаття 30 Проекту розуміє дії держави, викликані протиправними діями іншої держави. Таким чином, дії держави стосовно держави-правопорушниці, з погляду міжнародного права, будуть правомірними, тому що є провина самої потерпілої сторони. Мова, таким чином, йде про закономірні «відповідні заходи» - санкції, які можуть бути застосовані не тільки потерпілою державою, але також за їі дорученням компетентною міжнародною організацією $(\mathrm{OOH}$, відповідною регіональною організаціею) [7, с. 221].

Відповідно до міжнародного права порушення зобов'язання одним суб'єктом виправдовує прийняття потерпілим суб'єктом контрзаходів, які не повинні бути погрозою силою або їі застосуванням. Контрзаходи - це дії, які були б протиправними, якби не здійснювалися у відповідь на правопорушення 3 метою забезпечення припинення протиправного діяння і отримання відшкодування збитку [8, с. 75].

Положення, що відноситься до даного питання, закріплені в статті 22 Проекту. У гл. II Частини третьої викладаються умови, яким повинні відповідати контрзаходи. Контрзаходи застосовуються в основному державами, але не виключаеться їх застосування і міжнародними організаціям.

Правомірність контрзаходів, що відповідають певним матеріальним і процесуальним умовам, визнається судовою практикою i доктриною. У рішенні по справі про проект «Габчіково-Надьмарош» Міжнародний Суд визначив, що контрзаходи можуть виправдати в іншому випадку протиправні дії, «вжиті у відповідь на попереднє міжнародно-протиправне діяння іншої держави і ... спрямовані проти цієї держави» [6].

Як бачимо, будучи відповіддю на міжнародно-протиправні діяння іншої держави, контрзаходи виправдані лише по відношенню до ціеі держави. Проте, непрямий вплив контрзаходів може поширюватися на треті сторони. Як відомо, Міжнародний Суд визнав, що всі держави мають юридичний інтерес в дотриманні зобов'язань перед міжнародною спільнотою в цілому. Відносно таких випадків в Коментарі до Статей про відповідальність держав йдеться: «Хоча стаття 22 не охоплює заходи, які приймаються в подібних випадках, якщо вони не підпадають під визначення контрзаходів, вона також не виключає таку можливість» [10].

Протиправність діяння держави, що не відповідає їі міжнародному зобов'язанню, виключається, якщо діяльність держави була викликана фрорс-мажором (непереборною силою) або непередбаченим випадком (непередбаченими зовнішніми подіями).

Ці дві підстави розглядаються разом, тому що ні в міжнародній практиці, ні в доктрині немає чіткої і визначеної різниці між ними. Стосовно цих подій передбачається, що вони не дозволили державі діяти належним чином - відповідно до раніше прийнятого на себе зобов'язання або зрозуміти, що її поводження не відповідає цьому зобов'язанню.

При форс-мажорі і непередбаченому випадку мова може йти про ситуації, викликані явищами природи (землетрус, повінь, епідемія, епізоотія і т.д.) або діяльністю людей. В умовах таких ситуацій держава в особі своїх органів або посадових осіб опиняється в становищі об'єктивної неможливості обрати поведінку, що відповідає вимогам свого міжнародного зобов'язання, або встановити, що дана їі поведінка не відповідае необхідному. Слід зазначити, що фрорс-мажор як підстава для звільнення від відповідальності передбачений, наприклад, у статті 18 Конвенції ООН з морського права 1982 року [9, с. 87].

Ситуація крайнього лиха (стаття 32 Проекту) дуже схожа з форс-мажором або непередбаченим випадком, вона передбачає виключення протиправності діяння держави, якщо суб'єкт поведінки, що представляе дану державу, в умовах крайнього лиха не мав іншої можливості врятувати своє життя або життя ввірених йому людей.

Таким чином, дії суб'єкта, що представляе дану державу в ситуації крайнього лиха, тобто дії органу або особи, що представляють державу, стосуються лише захисту інтересів осіб, які піддаються надзвичайній небезпеці.

Найбільш яскравим прикладом зазначеної ситуації е дії капітана морського судна, яке терпить лихо, з укриття від шторму в іноземному порту, що чиняться без відповідного на це дозволу. У цьому випадку формально має місце порушення кордонів іншої держави, проте ці дії відбулися в силу виняткових обставин.

Лихо як обставина, що виключає відповідальність держави, передбачено, наприклад, у статті 98 Конвенції ООН з морського права 1982 року $[9$, с. 88$]$.

Слід, проте, мати на увазі, що держава усе ж буде відповідати, якщо вона сама сприяла виникненню ситуації крайнього лиха або якщо іï поведінка, про яку йде мова, могла викликати більш тяжке лихо. Наприклад, підводний човен із ядерною силовою установкою на борту, що потерпів серйозну аварію, може викликати ядерний вибух у порту іншої держави, де він намагається укритися і провести необхідний ремонт. У цьому випадку під загрозу буде поставлене життя величезної кількості людей і виникнуть найтяжчі наслідки. Тому держава, чий прапор несе підводний човен, не може бути звільнена від відповідальності [3, с. 115].

Стан необхідності (стаття 33 Проекту) передбачає обставини, коли крайній небезпеці піддаються суттєві інтереси держави. Правова регламентація такої ситуації в пункті 1 зазначеної статті виглядає таким чином: «Держава не може посилатися на стан необхідності як на підставу для виключення протиправності діяння цієї держави, що не відповідає їі міжнародному зобов'язанню, за винятком тих випадків, коли:

а) це діяння було единим засобом захисту суттевого інтересу цієї держави від тяжкої і неминучої загрози, i 
б) це діяння не завдало серйозної шкоди суттєвому інтересу держави, у відношенні якого існуе зазначена обставина».

Слід мати на увазі, що посилання держави на крайню необхідність правомірні лише при наявності ряду одночасно діючих умов:

- абсолютно винятковий характер ситуації, на яку посилається держава;

- неминучість характеру небезпеки, що загрожує життево важливим інтересам держави і їі населення;

- неможливість усунути таку небезпеку іншими засобами;

- в обов'язковому порядку тимчасовий характер дії, обмежений рамками періоду небезпеки [2, c. 57].

Пункт 2 статті 33 Проекту містить вказівку на випадки, коли держава не може посилатися на стан необхідності, а саме:

- міжнародне зобов'язання виникає з імперативної норми загального міжнародного права;

- міжнародне зобов'язання встановлене договором, що прямо або побічно виключає таку можливість;

- держава, про яку йде мова, сприяла виникненню стану необхідності.

3 огляду на той фракт, що дуже серйозні ускладнення виникають на практиці при визначенні того, чи є недотримання міжнародного зобов'язання державою єдиним засобом захисту її суттєвого інтересу, здається, що цінність правової регламентації ціеї ситуації, що представляе собою обставину, яка виключає міжнародно-правову відповідальність держав, полягає саме у визначенні випадків неприпустимості посилань на стан необхідності.

Міжнародно-правова відповідальність держави виключається, якщо держава, яка завдає шкоду іншій державі всупереч чинним нормам міжнародного права, діє з метою самооборони від агресії, у відповідності зі статтею 51 Статуту $\mathrm{OOH}$, що чиниться цією чи іншою державою.

Стаття 34 Проекту, названа "Самооборона», говорить: «Протиправність діяння держави, що не відповідае міжнародному зобов'язанню цієї держави, виключаеться, якщо це діяння є законним заходом самооборони, прийнятим відповідно до Статуту Організації Об'єднаних Націй» [10].

Згаданий в цій статті законний захід самооборони держави, відповідно до Статуту ООН, відповідає умовам його статті 51. Такими умовами є:

- наявність збройного нападу на державу іншої держави, що створюе винятково серйозну і явну загрозу їі територіальній цілісності і політичній незалежності, як це випливає 3 коментарю Комісії міжнародного права;

- самооборона здійснюеться доти, поки Рада Безпеки ООН не вживе заходів, необхідних для підтримки міжнародного миру і безпеки;

- Раді Безпеки повинно бути негайно повідомлено про вжиті заходи самооборони;

- заходи не торкаються повноважень і відповідальності Ради Безпеки в справі підтримки або відновлення міжнародного миру і безпеки [8, с. 165].

Самооборона повинна бути правомірною, яка здійснюеться відповідно до Статуту ООН і здійснюватися в рамках міжнародного права. Заходи, що вживаються в порядку самооборони, по- винні бути пропорційними і не виходити за межі необхідного. В ході самооборони держава залишається повністю зв'язаною зобов'язаннями, які регулюють поведінку в збройному конфрлікті.

Самооборона не виправдовує відступ від деяких зобов'язань, зокрема, від зобов'язань в області гуманітарного права і прав людини. Останні допускають лише певні обмеження гарантій, що містяться в них в разі надзвичайних ситуацій, до яких відноситься і стан самооборони.

Таким чином, самооборона розглядається як припустимий захід захисту територіальної цілісності та політичної незалежності держави, що піддалася збройному нападу, доти, поки не вступить у дію передбачена Статутом ООН система колективної міжнародної безпеки.

Обставини, що звільняють від відповідальності, необхідно відрізняти від фрактів та дій, які виключають кваліфікацію діяння суб'єкта в якості правопорушення. Серед таких фрактів та дій можна назвати:

- згоду потерпілої сторони на здійснення діяння, яке спричинило завдання шкоди;

- допустимі в рамках міжнародного права дії суб'єкта у відповідь на протиправну поведінку потерпілого (самооборона).

Прикладом вини потерпілої сторони може бути ситуащія, коли держава, знаючи, що готуеться замах на їі посольство, не сповіщає про це владу країни перебування посольства. Коли замах таки буде здійснено, держава перебування повинна нести відповідальність за порушення чи невиконання зобов'язання щодо забезпечення безпеки дипломатичного представництва іноземної держави. Якщо ж вона може довести, що посольство чи держава, яка його акредитувала, володіли інформацією про замах, що готувався, але не поділилися нею для спільного успішного захисту, то ця обставина може розглядатися як така, що спричиняе звільнення від відповідальності [9].

Загалом усі випадки передбачити неможливо, тому кожен з них вимагає диференційованого підходу.

Отже, існують обставини, при яких суб'єкт не несе відповідальності за діяння, яке не відповідає тому, що вимагає від нього міжнародне зобов'язання. Такими шістьма обставинами є згода, самооборона, контрзаходи, форс-мажор, лихо і стан необхідності. Мова, таким чином, йде про обставини, які в цілому притаманні праву держав, тобто являють собою загальні принципи права. Наведений перелік є вичерпним і загальновизнаним.

Висновки. Обставини, що звільняють державу від міжнародно-правової відповідальності, виконують функцію нормативного забезпечення нормального, безперебійного фрункціонування механізму міжнародно-правового регулювання та підтримки міжнародного правопорядку в тих випадках, якщо поведінка держави, зовні підпадає під формулу складу міжнародного правопорушення, кваліфікуеться як правомірна, оскільки фрактично відсутні підстави та передумови що покладають на дану державу відповідальності за міжнародні правопорушення. У цьому сенсі інститут обставин, які звільняють державу від міжнародно-правової відповідальності, тісно пов'язаний з інститутом відповідальності держа- 
ви за міжнародні правопорушення. Специоріка зв'язку, полягає в тому, що об'єктивним орієнтиром, що дозволяе відмежувати ситуації, коли держава звільняеться від міжнародно-правової відповідальності, і ситуації, в умовах яких така відповідальність може бути покладена на дану державу, є облік суб'єктивної сторони складу міжнародного правопорушення, тобто встановлення того, причетна, чи ні, дана держава до діяння, що порушуе взяте на себе певне міжнародне зобов'язання щодо відношення до іншо- го, з точки зору характеру реалізації властивої йому в силу державного суверенітету волі. Отже, якщо поведінка держави, що порушує певні міжнародні зобов'язання, є результатом відсутності неправомірно реалізованої волі ціеї держави, то воно не кваліфікуеться, як міжнародне правопорушення, а це в свою чергу веде до відсутності міжнародно-правової відповідальності держави. Іншими словами, в даному випадку мають місце обставини, які звільняють державу від міжнародно-правової відповідальності.

\section{Список літератури:}

1. Антонович М. М. Міжнародне публічне право : навчальний посібник для студентів вищих навчальних закладів. Київ : Вид. дім «КМ Академія», Алерта, 2003. 308 с.

2. Дмитриева Г. К. Мораль и международное право : монографія. Москва : Изд. «Международные отношения», 1991. $168 \mathrm{c.}$

3. Дмитріев А. І. та ін. Міжнародне публічне право : практикум / А.І. Дмитрієв, А. С. Мацко, В. I. Муравйов; Відп. ред. : Ю. С. Шемшученко, Л. В. Губерський. Київ : Юрінком Інтер, 2001. 339 с.

4. Іванов А. А. Цілі юридичної відповідальності, її функції і принципи. Держава і право. 2003. № 6. С. 67-70.

5. Конвенція про міжнародну відповідальність за шкоду, заподіяну космічними об'єктами 1972 р. URL: http://zakon5.rada.gov.ua/laws/show/995_ (дата звернення: 01.12.2020).

6. Краткое изложение решений, консультативных заключений и постановлений Международного Суда 1997-2002 гг. URL: http://legal.un.org/ICJSummaries/documents/russian/ST-LEG-SER-F-1-Add3_R.p (дата звернення: 02.12.2020).

7. Кузько А. В. Теоретичні питання забезпечення ефективності юридичної відповідальності. Iсторія держави і права. 2008. № 2. С. 43-45.

8. Левин Д. Б. Ответственность государств в современном международном праве : монографрия. Москва : Международные отношения, 1966. 152 с.

9. Мацко А. С. Міжнародне право : навчальний посібник. Київ : МАУП, 2005. 232 с.

10. Проект статей об ответственности государств за международно-противоправные деяния 2001 г. // Доклад Комиссии международного права о работе ее пятьдесят третьей сессии: Официальные отчеты ГА ООН, 56 сессия // Дополнение № 10 А/56/10. Нью-Йорк : ООН, 2001.

11. Тимченко Л. Д. Міжнародне право : підручник. Київ : Знання, 2012. 631 с.

\section{References:}

1. Antonovich M. M. (2003) Mizhnarodne publichne pravo: navchal'nyy posibnyk dlya studentiv vyshchykh navchal'nykh zakladiv [International Public Law: Tutorial for students of higher educational establishments]. Kiev: View. House "KM Academy". (in Ukrainian)

2. Dmitriev G. K. (1991) Moral'ne ta vzayemozalezhne pravo: monohrafiya [Moral and Interdependent Law: monograph]. Moscow: ed. "International relations". (in Russian)

3. Dmitriev A. I., Matsko A. S., Muraviev V. I., Shemshuchenko Y. S., Gubersky L. V. (2001) Mizhnarodne publichne pravo: praktykum [International Public Law: practicum]. (in Ukranian)

4. Ivanov A. A. (2003) Pratsi shchodo tsiley yurydychnoyi vidpovidal'nosti, yiyi funktsiyi ta pryntsypy [Proceedings of the Goals of legal liability, its functions and principles]. State and law, no. 6, pp. 67-70.

5. Convention on international liability for damage caused by space objects in 1972. URL: http://zakon5.rada.gov.ua/ Laws/show/995_ (accessed 01 December 2020).

6. Elegantly molded, advisory concluded and established international court 1997-2002. URL: http://legal.un.org/ icjsummaries/documents/russian/st-leg-ser-f 1-add3_r.p (accessed 02 December 2020).

7. Kusho A. V. (2008) Teoretychni pytannya zabezpechennya efektyvnosti yurydychnoyi vidpovidal'nosti [Theoretical issues of ensuring the effectiveness of legal liability]. History of state and law, no. 2. pp. 43-45.

8. Levin D. B. (1966) Transportuvannya imperiliv u m. Seredn'odnorod Pravoruch: monohrafiya [Transportation of emperils in Mezhdnudnorod Right: Monograph]. Moscow: Interdependent relations. (in Russian)

9. Matsko A. S. (2005) Mizhnarodne pravo: pidruchnyk [International Law: tutorial]. Kyiv: MAUP. (in Ukrainian)

10. UN (2001) Proekt statey pro stan imperiy dlya vzayemozalezhnykh anty-dobryv [Project of articles on state of emperories for interdependent-anti-fertilizers]. Proceeding of the Ophibed Posters GA UN, New York: UN.

11. Timchenko L. D. (2012) Mizhnarodne pravo: pidruchnyk [International Law: tutorial]. Kyiv: Knowledge. (in Ukrainian) 